\title{
Evaluation of Cost Efficiency of Beibu Gulf Port based on Super Efficiency DEA
}

\author{
Kerong Jian ${ }^{1,2}$ \\ ${ }^{1}$ School of Management \\ Guilin University of Technology \\ Guilin, China \\ ${ }^{2}$ Department of Finance \\ Guangxi University of Science and Technology \\ Liuzhou, China \\ jkr1027@126.com
}

\begin{abstract}
To study Chinese Beibu Gulf port's cost efficiency based on the cost evaluation index system, which is selecting net value of fixed assets, net assets, cost of prime operating, the number of employees as input indicators, and selecting prime operating revenue as well as net profit as the output indicators, we constructed a mode to evaluate the DEA' port company's cost-efficiency. The study found that the comprehensive efficiency of Beibu Gulf port DEA is effective compared with other 15 listed coastal port companies. It has large space in efficiency, longitudinally compared with Yantian port, Nanjing port, Xiamen port, Lianyungang port and Tangshan port, the top five port cities.
\end{abstract}

Keywords-Cost Efficiency; Beibu Gulf Port; Super Efficiency; DEA; Evaluation

\section{INTRODUCTION}

Ports play a pivotal role as an important infrastructure of national economic development. Developing the modern port logistics and improving the efficiency of port logistics have become an import issue related to the port modernization, comprehensive competitiveness of countries, and development of the regional economy sustainably. The efficiency of port logistics affects the whole process of logistics activities and other aspects of logistics system, which affect efficiency of the whole logistics network. Therefore, in order to improve the logistics efficiency and keep the port's sustainable competitive advantage, we need to understand what factors affect the efficiency of port logistics, and compare it with other ports, and put forward countermeasures to improve our country's international competitiveness of port logistics. The cost efficiency of port enterprises refers to the ability of port enterprises to obtain the best output with the least cost, and it is a measure to realize the minimum cost or maximum output of the port enterprises. With the rapid development of port business and diversification of services, the competition is becoming increasingly fierce, and the port enterprises are increasingly feeling the importance and urgency of improving their efficiency, thus cost efficiency of port enterprises has important practical significance.

There are a lot of literatures analyzing logistics efficiency in China. Wang Changjiang [1] combined with the current situation and development trend of port logistics in Ningbo-Zhoushan port, this paper studies the basic concepts of modern logistics, the measurement and evaluation of modern logistics efficiency, and puts forward countermeasures of improving efficiency. Yun Jun and Zhang Fan [2] used the DEA model to evaluate eight ports. Li Tan [3] analyzed the port logistics efficiency of Liaoning Province in 2001-2009 in order to evaluate the port logistics efficiency in Liaoning Province, and through the construction of port logistics and hinterland economic cooperative development index system, calculated from 2002 to 2009 in Liaoning Province, port logistics and economic cooperation. Chen Shuangxi and Dai Minghua [4] analyzed main factors affecting the efficiency of port logistics as well as Northeast Asia port logistics development status and trends, and pointed out the current restricts the Northeast Asia port logistics efficiency improve the main bottleneck factor, put forward the technology of tapping the potential synergies, ring soft environment construction and operation of the integration strategy and countermeasures. Yu Hongsheng [5] expounds the relationship between port and port logistics, puts forward the concept of port service supply chain, and points out that the key to improve the efficiency of port logistics is to improve the management level. According to the connotation of logistics efficiency of international shipping center, Nin Chengcheng [6] established a multilevel port logistics competitiveness evaluation index system, using Delphi Method to determine the weight of all levels, and the use of fuzzy comprehensive evaluation method to evaluate the logistics efficiency of nine port cities: Shanghai, Tianjin, Qingdao, Nanjing, Suzhou, Xiamen, Ningbo and Shenzhen, Dalian international shipping center in logistics efficiency. Li Ying [7] established the index evaluation system for the container line density and hinterland freight demand as well as the coupling degree model and coordination model.

In this paper, we'll make empirical study on the efficiency of Beibu Gulf port of China from 2006 to 2013 by using the super efficiency DEA model, to study the change of the total factor productivity of each port during this period, to provide some data supporting the development of Beibu Gulf Port.

\section{RESEARCH METHOD AND DATA SOURCE}

\section{A. Research Method}

DEA improved model - the Super Efficiency DEA(SEDEA) makes up the traditional CCR-DEA model and 
BBC-DEA model because multiple simultaneous effective decision-making unit can't make further evaluation and comparison of the defect, so that effective decision-making unit can be compared, and inefficient decision-making unit efficiency value is consistent with the CCR-DEA model.

Assume that there are an independent decision-making unit (DMU), the $\mathrm{j}$ DMU has $\mathrm{m}$ kind of resource input $\mathrm{x}$ and $s$ kind of output $y$, and it is the basic idea of super efficiency DEA model: during the $\mathrm{j}$ DMU efficiency evaluation, so that the input and output of the $\mathrm{j}$ DMU would be replaced by all other inputs and outputs of decision-making unit and a linear combination, so the $\mathrm{j}$ decision-making unit will be excluded, avoiding the traditional DEA model for multiple simultaneous effective decision-making unit cannot be further compared. Super Efficiency DEA model is:

$$
\begin{gathered}
\min \theta_{0} \\
\text { s.t. } \sum_{j=1}^{n} \lambda_{j} x_{j i}+s_{i}^{-}=\theta_{0 x_{i 0}} i=1,2, \cdots, m \\
\sum_{\substack{j=1 \\
j=j_{0}}}^{n} \lambda_{j} y_{j r}-s_{r}^{+}=y_{r 0} r=1,2, \ldots, s \\
\lambda_{j} \geq 0, j=1,2, \cdots, n \\
s_{r}^{+} \geq 0, s_{i}^{-} \geq 0
\end{gathered}
$$

In the formula, $\theta_{0}$ is the efficiency value of decisionmaking unit, $\lambda_{j}$ is related to $D M U_{0}$, which is $\mathrm{j}$ decision-making unit combination proportion in a reconstruct effective DMU combination. $S_{r}^{+}$and $S_{i}^{-}$are slack variables. When $\theta_{0} \geq 1, S_{r}^{+}=S_{i}^{-}==0, D M U_{0}$ is the DEA effective technology, the formation of the efficient frontier surface is constant returns to scale, and decision-making unit is technology effectively and scale efficiently; when $\theta_{0} \leq 1$ or $S_{r}^{+} \neq 0, S_{i}^{-} \neq 0$, the decision-making unit is not effective, if $S_{r}^{+}=S_{i}^{-}==0$, the technology effectively, making $\theta_{0} \sum_{\substack{j=1 \\ j \neq j_{0}}} \lambda_{j}$, when $\mathrm{k}=1$, the decision-making unit is the constant return to scale; when $\mathrm{k}<1$, the decision-making unit is the increasing return to scale; when $\mathrm{k}>1$, the decision-making unit is the decreasing return to scale.

\section{B. Data SOURCE}

There are many methods to evaluate the efficiency of a port, but there is no uniform standard for the input and output of the cost efficiency of the listing Corporation. Among them, Liu (1995) [8] selected input indicators including per capita wages, the carrying accounting of the fixed assets and total assets, and the output index is the total throughput, analysis and evaluation of the model used for SFA stochastic frontier production function;
Martinez (1999) [9] of the input indicators including wage, costs, depreciation, and other expenses, such as the total cargo throughput, output index port profit, evaluation model for the CCR-DEA model and BCC-DEA model; Chen Junfei (2004) [10] choose the index from the financial perspective, the input indicators include the assets of the company, the cost of circulation shares, the number of employees, and cost of prime operating, including the output index of earnings per share, net profit, prime operating revenue, using the evaluation model for the CCR-DEA model; Kuang Haibo (2007)[11] selects 4 input indicators: net value of fixed assets, net assets, cost of prime operating, the number of employees and 3 output indicators: prime operating revenue, net profit, earnings per share. In summary, from the availability of data we'll get the following input-output index.

1. The setting of input variables. Net value of fixed assets is $\left(X_{1}\right)$, net assets are $\left(X_{2}\right)$, cost of prime operating is $\left(X_{3}\right)$, and the number of employees is $\left(X_{4}\right)$.

2. The setting of output variable. Prime operating revenue is $\left(Y_{1}\right)$ and net profit is $\left(Y_{2}\right)$.

3. Sample selection. This paper we'll select the sample during the main longitudinal dynamic data samples from 2007 to 2013, transverse data is the 16 listed coastal ports companies in 2014. All the data are from "Statistical Yearbook of China Port" and the "Shanghai Stock Exchange" and "Shenzhen Stock Exchange" released each

\begin{tabular}{|c|c|c|c|c|c|c|}
\hline $\begin{array}{c}\text { Name of } \\
\text { port }\end{array}$ & $Y_{1}$ & $Y_{2}$ & $X_{1}$ & $X_{2}$ & $X_{3}$ & $X_{4}$ \\
\hline Yantian & $\begin{array}{c}3008 \\
5 \\
\end{array}$ & 43999 & 16531 & 512121 & 13292 & 537 \\
\hline Nanjing & $\begin{array}{c}1520 \\
27\end{array}$ & 2045 & 36525 & 63552 & 9773 & 705 \\
\hline $\begin{array}{l}\text { Lianyun } \\
\text { gang }\end{array}$ & $\begin{array}{c}1529 \\
37\end{array}$ & 10371 & 194592 & 321361 & 120158 & 4550 \\
\hline $\begin{array}{c}\text { Chiwan } \\
\text { A }\end{array}$ & $\begin{array}{c}1804 \\
77 \\
\end{array}$ & 41759 & 331984 & 422062 & 98389 & 1744 \\
\hline $\begin{array}{c}\text { Chongqi } \\
\text { ng }\end{array}$ & $\begin{array}{c}1895 \\
30\end{array}$ & 9558 & 353764 & 328099 & 149393 & 2254 \\
\hline Jinzhou & $\begin{array}{c}2126 \\
99\end{array}$ & 22083 & 799606 & 580600 & 160815 & 1482 \\
\hline Zhuhai & $\begin{array}{c}2139 \\
04\end{array}$ & 1714 & 176722 & 245011 & 182028 & 1259 \\
\hline Yingkou & $\begin{array}{c}3910 \\
48\end{array}$ & 53967 & $\begin{array}{c}118180 \\
5\end{array}$ & 951931 & 269305 & 4454 \\
\hline Beibu & $\begin{array}{c}4237 \\
73\end{array}$ & 59659 & 614548 & 395347 & 309571 & 2466 \\
\hline Rizhao & $\begin{array}{c}5083 \\
60\end{array}$ & 57251 & 989957 & 995610 & 376230 & 5394 \\
\hline $\begin{array}{c}\text { Tangsha } \\
\mathrm{n}\end{array}$ & $\begin{array}{c}5126 \\
63\end{array}$ & 108899 & 782759 & 768533 & 307952 & 3224 \\
\hline Xiamen & $\begin{array}{c}7502 \\
33\end{array}$ & 28666 & 83081 & 254052 & 712480 & 3731 \\
\hline Dalian & $\begin{array}{c}7942 \\
46 \\
\end{array}$ & 52067 & $\begin{array}{c}147663 \\
9 \\
\end{array}$ & $\begin{array}{c}137179 \\
4 \\
\end{array}$ & 656756 & 6820 \\
\hline Ningbo & $\begin{array}{c}1341 \\
521\end{array}$ & 281863 & $\begin{array}{c}195186 \\
0\end{array}$ & $\begin{array}{c}307571 \\
2\end{array}$ & 926278 & $\begin{array}{c}1169 \\
8\end{array}$ \\
\hline Tianjin & $\begin{array}{c}2552 \\
830\end{array}$ & 115191 & $\begin{array}{c}137050 \\
5 \\
\end{array}$ & $\begin{array}{c}135523 \\
8 \\
\end{array}$ & $\begin{array}{c}221522 \\
2\end{array}$ & 7867 \\
\hline Shanghai & $\begin{array}{c}2877 \\
870\end{array}$ & 676655 & $\begin{array}{c}356377 \\
3\end{array}$ & $\begin{array}{c}556289 \\
6\end{array}$ & $\begin{array}{c}182496 \\
5\end{array}$ & $\begin{array}{c}1904 \\
4\end{array}$ \\
\hline
\end{tabular}
listed company's financial report.

\section{DATA AND DATA ANLYSIS}

TABLE I. THE DATA OF THE INPUT AND OUTPUT VARIABLES UNIT:TEN THOUS AND YUAN 
TABLE II. THE COST EFFICIENCY OF THE PORT COMPANIES

\begin{tabular}{|l|l|l|l|l|l|}
\hline $\mathbf{S}$ & \multicolumn{1}{|c|}{$\begin{array}{c}\text { Name of } \\
\text { Port } \\
\text { Comprehensi } \\
\text { ve Efficiency }\end{array}$} & $\begin{array}{c}\text { The Pure } \\
\text { Technical } \\
\text { Efficienc } \\
\mathbf{y}\end{array}$ & $\begin{array}{c}\text { The } \\
\text { Scale } \\
\text { Efficie } \\
\text { ncy }\end{array}$ & $\begin{array}{c}\text { The } \\
\text { Return } \\
\text { s to } \\
\text { Scale }\end{array}$ \\
\hline 1 & Yantian & 1.000 & 1.000 & 1.000 & - \\
\hline 2 & Nanjing & 1.000 & 1.000 & 1.000 & - \\
\hline 3 & $\begin{array}{l}\text { Lianyungan } \\
\text { g }\end{array}$ & 0.364 & 0.509 & 0.714 & drs \\
\hline 4 & Chiwan A & 0.872 & 0.878 & 0.993 & irs \\
\hline 5 & Chongqing & 0.382 & 0.566 & 0.676 & drs \\
\hline 6 & Jinzhou & 0.650 & 0.681 & 0.954 & drs \\
\hline 7 & Zhuhai & 0.632 & 0.633 & 0.998 & irs \\
\hline 8 & Yingkou & 0.504 & 0.722 & 0.698 & drs \\
\hline 9 & Beibu & 1.000 & 1.000 & 1.000 & - \\
\hline 10 & Rizhao & 0.502 & 0.756 & 0.664 & drs \\
\hline 11 & Tangshan & 1.000 & 1.000 & 1.000 & - \\
\hline 12 & Xiamen & 1.000 & 1.000 & 1.000 & - \\
\hline 13 & Dalian & 0.507 & 0.784 & 0.647 & drs \\
\hline 14 & Ningbo & 0.778 & 0.878 & 0.886 & drs \\
\hline 15 & Tianjin & 1.000 & 1.000 & 1.000 & - \\
\hline 16 & Shanghai & 1.000 & 1.000 & 1.000 & - \\
\hline & Average & 0.762 & 0.838 & 0.889 & \\
\hline & & & & & \\
\hline
\end{tabular}

\section{THE COST EFFECTIVENESS ANALYSIS}

DEA efficiency is 1: Yantian port, Nanjing port, Beibu gulf port, Tangshan port, Xiamen port, Tianjin port and the Shanghai port account for about $37.5 \%$ of the sample; The increasing returns to scale with deep Chiwan A, Zhuhai port, diminishing returns to scale in Lianyungang port, Chongqing port, Jinzhou port, Yingkou port, Rizhao port, Dalian port, Ningbo port, the rest of the port company keeps returns to scale unchanged. In the case of the input, the port company should achieve comprehensive efficiency, and the output can improve the space such as in Table 3, in the case of the output to maintain the same, its investment targets can be reduced as shown in Table 4.

TABLE III. OUTPUT INDICATORS SLACK VARIABLE VALUE (LESS OUTPUT VALUE)

\begin{tabular}{|l|l|l|l|}
\hline $\begin{array}{l}\text { Serial } \\
\text { Number }\end{array}$ & $\begin{array}{l}\text { Name of } \\
\text { Port }\end{array}$ & Output 1 & Output 2 \\
\hline 1 & Yantian & 0.000 & 0.000 \\
\hline 2 & Nanjing & 0.000 & 0.000 \\
\hline 3 & Lianyungang & 0.000 & 9193.163 \\
\hline 4 & Chiwan A & 10867.154 & 0.000 \\
\hline 5 & Chongqing & 0.000 & 16270.897 \\
\hline 6 & Jinzhou & 0.000 & 0.000 \\
\hline 7 & Zhuhai & 0.000 & 8090.387 \\
\hline 8 & Yingkou & 0.000 & 23733.374 \\
\hline 9 & Beibu & 0.000 & 0.000 \\
\hline 10 & Rizhao & 0.000 & 39174.129 \\
\hline 11 & Tangshan & 0.000 & 0.000 \\
\hline 12 & Xiamen & 0.000 & 0.000 \\
\hline 13 & Dalian & 0.000 & 90612.373 \\
\hline 14 & Ningbo & 0.000 & 21548.417 \\
\hline 15 & Tianjin & 0.000 & 0.000 \\
\hline 16 & Shanghai & 0.000 & 0.000 \\
\hline & Average & 679.197 & 13038.921 \\
\hline
\end{tabular}

TABLE IV. THE SE- DEA VALUE OF THE PORT COMPANIES
\begin{tabular}{|l|l|l|l|l|}
\hline SN & $\mathbf{1}$ & $\mathbf{2}$ & $\mathbf{3}$ & $\mathbf{4}$ \\
\hline DMU & Yantian & Nanjing & Xiamen & Lianyungang \\
\hline Score & $1361.54 \%$ & $835.40 \%$ & $225.09 \%$ & $124.29 \%$ \\
\hline SN & $\mathbf{5}$ & $\mathbf{6}$ & $\mathbf{7}$ & \\
\hline DMU & Tangshan & Beibu gulf & Shanghai & \\
\hline Score & $112.18 \%$ & $109.67 \%$ & $101.26 \%$ & \\
\hline
\end{tabular}

\section{CONCLUSION}

In this paper, we evaluate the cost efficiency of Beibu Gulf port by using the improved model of DEA, super efficiency DEA (SE-DEA), analyze the logistics cost of the Beibu Gulf 2006-2013, make up the shortcomings of the traditional CCR-DEA model and BBC-DEA model, and provide some data support to the development of the Beibu Gulf port.

Through the SE-DEA model established in this paper of Beibu Gulf and the other 15 listed coastal port companies, the pure technical efficiency, scale efficiency, further evaluation of the returns to scale and comprehensive efficiency analysis that Beibu Gulf port relative Yantian port, Nanjing port, Xiamen port, and Lianyungang, not only for the DEA efficiency, but there is also still a lot of room to improve the efficiency.

But this paper only focuses on northern Gulf port and its port input indicators: fixed assets, net assets, the main business costs, the number of employees and output indicators: the main business income and net profit are compared, and the financial aspects of the port company's comprehensive assessment of net assets yield is also worth further study.

\section{ACKNOWLEDGMENT}

This paper was supported by 1) the outstanding young backbone teachers' training program in higher educational institutions of Guangxi, China; 2) Guangxi Philosophy and Social Science Fund (The Grant No. 13BGL009) and 3) The teaching reform project in higher education of Guangxi (No. 2012JGA178).

\section{REFERENCES}

[1] Wang Changjiang. Port modern logistics: concept interpretation, efficiency evaluation and promotion strategy -- a discussion on the construction of Zhoushan Ningbo port under the background of the green concept [J]. management world, 2008,06:180-181.

[2] Yun Jun, Zhang Fan. Evaluation of port logistics efficiency based on DEA model [J]. statistics and decision, 2006,19:39-40.

[3] Li Tan, Wang Li, Wang Yu. Research on the port logistics efficiency of Liaoning province and the cooperative development of the hinterland economy, [J]., 2012,09:108-113.

[4] Chen Shuangxi, Dai Minghua. Evaluation model of port competitiveness and evaluation of port competitiveness of Northeast Asia [J]. Journal of Dalian Maritime University (SOCIAL SCIENCE EDITION), 2006,04:39-43.

[5] Yu Hongsheng. Construction of port service supply chain to improve the port logistics efficiency of $[\mathrm{J}]$. port technology, 2008,05:1-3+8.

[6] Ni Chengcheng, Lin Guolong. Comparative study based on the DEA model of Shanghai international shipping center and logistics efficiency $[\mathrm{J}]$. Wuhan Science Journal of University of Technology 
(Transportation Science and Engineering Edition), 2012,04:857860.

[7] Li Ying, Jia Peng. Analysis of the coupling degree between the port container shipping density and hinterland cargo demand analysis [J]. Journal of Dalian Maritime University, 2011,03:51-54.

[8] Liu Z. The comparative performance of public and private enterprises[J]. Journal o f Transportation Economics and Policy, 1995 (September):263 - 274.

[9] Martinez B. E., Diaz A. R., Navarro I. M., etc. A study of the efficiency of Spanish port authorities using data envelopment analy sis [J]. International Journal of Transport Economics, 1999, 26 (2): $237-253$.

[10] Chen Junfei, Xu Changxin, Yan, a new method for evaluating the operational efficiency of port water transport listing Corporation (J]. 2004, 25 (1): 55 - 51

[11] Kuang Haibo. Evaluation of cost efficiency of Chinese port listing Corporation based on super efficiency [J]. CCR-DEA China management science, 2007,03:142-14857670. 